\title{
Analisis roadshow Gubernur Gandjar Pranowo sebagai perwujudan peran dan fungsi wakil pusat di daerah
}

\section{Erlin Nur Marfuah}

\author{
Sekertariat Daerah (Setda) Provinsi Jawa Tengah, Indonesia
}

\section{INTISAR|}

Penelitian ini memfokuskan diri terhadap kajian pelaksanaan roadshow Gubernur Ganjar Pranowo Tahun 2013-2017 sebagai perwujudan peran dan fungsi gubernur wakil pemerintah pusat di daerah serta merumuskan rekomendasi berdasarkan hasil analisis yang diperoleh agar peran dan fungsi gubernur sebagai wakil pemerintah pusat di daerah dapat berperan optimal. Metode yang dipakai dalam penelitian ini menggunakan metode kualitatif dengan proporsi dominan menggunakan Studi pustaka dilakukan untuk membangun kerangka teori melalui studi literatur dengan menelusuri berbagai teori, hasil penelitian, studi terdahulu yang telah dilakukan yang berhubungan dengan kedudukan, peran dan fungsi gubernur dalam sistem pemerintahan. Telaah dokumen dilakukan untuk mendapatkan berbagai bahan, data, informasi yang berkaitan dengan Roadshow Gubernur Jawa Tengah ke 35 kabupaten/kota pada tahun 2013- 2017 yang diperkuat dengan wawancara terhadap informan di Biro Administrasi Pembangunan Daerah selaku OPD leading sector pelaksanaan roadshow Gubernur. Hasil temuan, ternyata roadshow Gubernur Ganjar Pranowo Tahun 2013-2017 dilakukan tidak merata atau terjadi ketimpangan di 35 kabupaten kota. Dengan rincian kabupaten yang sering dikunjungi adalah Kabupaten Cilacap sebanyak 36 kali dan Kabupaten yang jarang dikunjungi adalah Kabupaten Sukoharjo dan Kota Magelang sebanyak 2 kali . Bentuk dari kegiatan Roadshow Gubernur ada 6 (enam) yaitu: Ngopi Bareng/Rembukan; Gubernur Mengajar; Silaturahmi ke Pondok Pesantren; Pengarahan SKPD Kabupaten/Kota; Peninjauan Infrastruktur dan Peninjauan UPT/Balai/UP3AD. Dari hasil identifikasi kegiatan roadshow yang dilakukan penulis, Peninjauan Infrastruktur adalah kegitan yang paling sering dilakukan. Kegiatan Roadshow Gubernur di 35 kabupaten/kota mencerminkansebagian besar perwujudan peran dan fungsi gubernur sebagai wakil pemerintah pusat di daerah dan menjalankan kewenangan atributif (fungsi kordinasi, pembinaan dan pengawasan).

\section{KATA KUNCI}

Roadshow;

Kewenangan Atributif;

Kewenangan

Delegatif

\section{Korespodensi:}

Biro Administrasi Pembangunan, Sekertariat Daerah Provinsi Jawa Tengah, Jl. Pahlawan No.9, Mugassari, Semarang Sel., Kota Semarang, Jawa Tengah 50249.

Email: hany.eyin@gmail.com. 


\section{Pendahulluan}

$\mathrm{U}$

ndang-Undang Dasar Negara Republik Indonesia Tahun 1945 Pasal 18, Pasal 18A, dan Pasal 18B memberikan hak kepada daerah untuk menyelenggarakan pemerintahan di daerahnya sendiri berdasarkan asas otonomi dan tugas pembantuan. Dalam Pasal 18 secara tegas menyebutkan bahwa, ayat (1) Negara Kesatuan Republik Indonesia dibagi atas daerahdaerah provinsi dan daerah provinsi itu dibagi atas kabupaten dan kota, yang tiap-tiap provinsi, kabupaten dan kota itu mempunyai pemerintahan daerah, yang diatur dengan undang-undang. Ayat (2) Pemerintahan daerah provinsi, daerah kabupaten, dan kota mengatur dan mengurus sendiri urusan pemerintahan menurut asas otonomi dan tugas pembantuan.

Pengaturan pada setiap Undang-Undang tentang Pemerintahan Daerah telah memberikan peranan yang strategis kepada kepala daerah, mengingat kepala daerah merupakan unsur penentu berkaitan pada keberhasilan pembangunan nasional, karena pemerintahan daerah merupakan subsistem dari pemerintahan nasional atau negara (Kaloh, 2010). Hal ini berarti hanya provinsi yang memiliki status sebagai wilayah administrasi sekaligusdaerah otonom (fused model) serta hanya gubernur yang memiliki kedudukan dan peran ganda (dual role), yaitu sebagai wakil pemerintah pusat di wilayah provinsi dan selaku kepala daerah. Sementara, kedudukan kabupaten/ kota adalah daerah otonom murni yang menyelenggarakan desentralisasidan bupati/walikota hanya berkedudukan sebagai kepala daerah. Pelaksanaan tugas dan kewenangan Gubernur sebagai Wakil Pemerintah Pusat di daerah yang memiliki banyak kendala, menjadi salah satu tantangan tersendiri bagi Jawa Tengah dalam masa kepemimpinan Ganjar Pranowo, Gubernur Jawa Tengah 2013-2018.

Untuk mewujudkan Misi Kelima yaitu memperkuat Partisipasi Masyarakat dalam Pengambilan Keputusan dan Proses Pembangunan yang Menyangkut Hajat Hidup Orang Banyak, telah dilakukan beberapa perubahan dalam proses penjaringan aspirasi masyarakat salah satunya dengan roadshow. Adapun roadshow dilakukan sangat intens dari Rabu sampai dengan Jumat setiap minggunya. Dari Data Internal Biro Administrasi Pembangunan Daerah Setda Provinsi Jawa Tengah, Gubernur Ganjar Pranowo telah melakukan 633 kunjungan tempat baik pada saat roadshow, acara pribadi, maupun acara lainnya dalam kurun waktu 52 bulan (4 tahun 4 bulan) di 35 kabupaten/kota yang dimulai dari akhir Oktober 2013 sampai Januari 2018.

Melalui roadshow, aspirasi masyarakat diserap dan dihimpun kemudian digunakan untuk memberikan masukan serta pertimbangan kepada pemerintah pusat maupun kabupaten/kota terkait cara mengatasinya dalam jangka pendek/ jangka panjang guna perbaikan ke depan. Roadshow juga untuk meningkatnya keterlibatan masyarakat dalam proses perencanaan, pelaksanaan dan pengawasan pembangunan; berkurangnya kesenjangan pembangunan antar wilayah; dan meningkatnya ketepatan waktu dan mutu pelaksanaan pembangunan daerah. Sehingga perlu diciptakan sebuah mekanisme hubungan yang saling bersinergi dan berkoordinasi antara pemerintah pusat dan pemerintah daerah serta antarpemerintah daerah dalam konteks menyukseskan otonomi daerah dan dalam upaya untuk menyejahterakan rakyat. 
Dengan latar belakang sebagaimana diuraikan di atas, maka tulisan ini akan berusaha mengupas dua pembagasan utama. Pertama, bagaimanakah pelaksanaan roadshow gubernur di 35 kabupaten/kota sebagai perwujudan peran dan fungsi gubernur sebagai wakil pemerintah pusat di daerah pada masa pemerintahan Gubernur Ganjar Pranowo. Kedua, apa saja faktor pendorong dan faktor penghambat kegiatan roadshow Gubernur Ganjar Pranowo sebagai perwujudan peran dan fungsi gubernur sebagai wakil pemerintah pusat di daerah pada masa pemerintahan Gubernur Ganjar Pranowo.

\section{Fungsi dan Kewenangan: Dasar Teoritik}

Artikel ini berangkat dari penelitian yang menggunakan metode kualitatif dengan proporsi dominan menggunakan Studi pustaka dilakukan untuk membangun kerangka teori melalui studi literatur dengan menelusuri berbagai teori, hasil penelitian, studi terdahulu yang telah dilakukan yang berhubungan dengan kedudukan, peran dan fungsi gubernur dalam sistem pemerintahan. Telaah dokumen dilakukan untuk mendapatkan berbagai bahan, data, informasi yang berkaitan dengan Roadshow Gubernur Jawa Tengah ke 35 kabupaten/kota pada tahun 2013- 2017 yang diperkuat dengan wawancara terhadap informan di Biro Administrasi Pembangunan Daerah selaku OPD leading sektor pelaksanaan roadshow Gubernur.

Dalam penulisan ini, ada dua konsep kunci yang akan dipakai, yakni sistem perfektoral dan teori kewenangan. Kedua hal inilah yang akan dijadikan sebagai dasar teoritik dalam membaca persoalan yang diangkat. Adapun penjelasan kedua hal ini, bisa dijelaskan sebagai berikut.

\section{Sistem Prefektoral}

Pemerintah pusat modern dapat menerapkan kebijakan di seluruh wilayahnya dengan menggunakan tiga pola dasar struktur administrasi, yakni: (1) functional pattern of field administration, (2) prefectoral pattern of field administration, dan (3) decentralization (Fried, 1963: 301). Menurut Fried, pola fungsional dan desentralisasi telah memperoleh perhatian yang luas dan dipelajari secara intensif. Namun sistem prefectoral belum mendapat banyak perhatian ilmiah meskipun fakta menunjukkan bahwa sistem tersebut dapat ditemukan di sebagian besar negara di dunia.

Salah satu pejabat administratif paling awal dalam sejarah adalah keberadaan wakil raja atau kaisar, sebagai bagian dari birokrasi kerajaan (Jones, 1985). Wakil raja atau kaisar dalam konteks ini adalah merupakan wakil pemerintah dalam struktur pemerintahan secara keseluruhan. Jones menambahkan pada abad pertengahan di Inggris wakil pemerintah dipegang oleh sheriff, pada abad ke-18 Prancis terdapat intendant, di Prusia disebut landrat, di China dan negara-negara Islam adalah gouvernour, dan salah satu yang paling populer dan memiliki fenomena tersendiri adalah prefect (prefek) Romawi. Wakil kerajaan tersebut umumnya ditempatkan di provinsi sebagai bagian dari kekuasaan pusat/kerajaan untuk menegakkan perintah kerajaan yang memiliki berbagai fungsi, diantaranya: militer, peradilan, politik dan administrasi, seperti: menarik pajak, mengatur irigasi, menjaga perdamaian, dan pekerjaan publik lainnya. 


\section{Teori Kewenangan}

Kewenangan dalam Kamus Besar Bahasa Indonesia berasal dari kata dasar "wewenang" yang artinya hak dan kekuasaan yang dimiliki. Sedangkan kewenangan adalah hak atau kekuasaan yang dimiliki untuk melakukan sesuatu (Depdiknas, 2005: 1921). Sementara itu, kekuasaan berasal dari kata dasar "kuasa" kemampuan atau kesanggupan (untuk berbuat sesuatu), kekuatan, wewenang atas sesuatu untuk memerintah. Sedangkan kekuasaan adalah kuasa untuk memerintah, kemampuan atau kesanggupan (Soekanto, 1975: 61).

Soekanto (1975) secara tegas membedakan antara "kekuasaan" (power) dengan wewenang (authority). Menurutnya, kekuasaan merupakan sesuatu kemampuan atau kekuatan seseorang/ segolongan untuk mempengaruhi pihak lain, sedangkan wewenang adalah kekuasaan yang mendapat pengakuan dan dukungan dari masyarakat. Jadi dalam pengertian wewenang, sudah mencakup hak dan kekuasaan untuk memberi perintah atau bertindak untuk mempengaruhi tindakan orang lain, agar sesuatu dilakukan sesuai dengan yang diinginkan.

Desain yang meletakkan dekonsentrasi dan desentralisasi di provinsi berbasiskan pada konsep Fused Model, Integrated Field Administration, dan Integrated Prefectoral System. Teori tersebut memiliki karakteristik substansi yang identik dalam aspek kewilayahan, wewenang dan fungsi yang melekat kepada kepala daerah otonom maupun kepala wilayah administrasi atau wakil pemerintah pusat.

Andy \& Bakry (2009) mengemukakan, dalam pengaturan kedudukan gubernur sebagai wakil pemerintah, ruang lingkup tugas dan wewenang hendaknya dikonstruksi ke dalam dua bentuk. Pertama, kewenangan yang melekat pada jabatannya sebagai kepala wilayah (gewestelijke bestuurshoofden), atau bentuk kewenangan integrated field administration yang seharusnya dimaknai sebagai tugas-tugas pemerintahan umum. Kedua, kewenangan atas urusan-urusan departemen teknis yang dilimpahkan kepada gubernur sebagai wakil pemerintah (delegative authority), atau disebut juga "fragmented field administration" seperti yang dikemukakan Leemans (dalam Andy \& Bakry, 2009). Konstruksi peran dan fungsi gubernur sebagai wakil pemerintah pusat dibagi menjadi dua, yakni kewenangan atributif dan kewenangan delegatif.

Kewenangan atributif merupakan kewenangan yang melekat pada gubernur sebagai kepala wilayah administrasi. Dalam kewenangan atributif tersebut terdapat sejumlah peran dan fungsi, meliputi: (1) Melaksanakan Urusan Pemerintahan Umum; (2) Menjalankan Fungsi Koordinasi, Pembinaan, dan Pengawasan (3) Menjalankan Fungsi Koordinator dan Integrator Instansi Vertikal. Sedangkan, kewenangan delegatif, merupakan kewenangan yang berkaitan dengan pelimpahan wewenang urusan-urusan kementerian teknis kepada gubernur sebagai wakil pemerintah pusat.

\section{Roadshow 35 kabupaten/kota: Perwujudan peran dan fungsi gubernur}

Gubernur Ganjar Pranowo melakukan roadshow di 35 kabupaten kota yang dimulai pada akhir tahun 2013 sampai dengan akhir tahun 2017. Dari hasil identifikasi kegiatan roadshow yang dilakukan penulis, roadshow dilakukan tidak merata atau terjadi ketimpangan di 35 kabupaten kota. Dengan rincian Kabupaten yang sering dikunjungi adalah Kabupaten Cilacap sebanyak 
36 kali dan Kabupaten yang jarang dikunjungi adalah Kabupaten Sukoharjo dan Kota Magelang sebanyak 2 kali.

Tabel 1: Jumlah Roadshow di 35 Kabupaten/Kota Tahun 2013-2017

\begin{tabular}{|c|c|c|}
\hline No & Nama Kabupaten & Jumlah (Kali) \\
\hline 1 & Banjarnegara & 13 kali \\
\hline 2 & Banyumas & 34 kali \\
\hline 3 & Batang & 13 kali \\
\hline 4 & Blora & 7 kali \\
\hline 5 & Boyolali & 7 kali \\
\hline 6 & Brebes & 24 kali \\
\hline 7 & Cilacap & 36 kali \\
\hline 8 & Demak & 14 kali \\
\hline 9 & Grobogan & 17 kali \\
\hline 10 & Jepara & 9 kali \\
\hline 11 & Karanganyar & 12 kali \\
\hline 12 & Kebumen & 9 kali \\
\hline 13 & Kendal & 13 kali \\
\hline 14 & Klaten & 17 kali \\
\hline 15 & Kudus & 10 kali \\
\hline 16 & Magelang & 5 kali \\
\hline 17 & Pati & 12 kali \\
\hline 18 & Pekalongan & 6 kali \\
\hline 19 & Pemalang & 13 kali \\
\hline 20 & Purbalingga & 10 kali \\
\hline 21 & Purworejo & 13 kali \\
\hline 22 & Rembang & 5 kali \\
\hline 23 & Semarang & 12 kali \\
\hline 24 & Sragen & 11 kali \\
\hline 25 & Sukoharjo & 2 kali \\
\hline 26 & Tegal & 8 kali \\
\hline 27 & Temanggung & 15 kali \\
\hline
\end{tabular}




\begin{tabular}{|r|l|r|}
\hline No & Nama Kabupaten & \multicolumn{1}{|c|}{ Jumlah (Kali) } \\
\hline 28 & Wonogiri & 9 kali \\
\hline 29 & Wonosobo & 18 kali \\
\hline 30 & Kota Semarang & 24 kali \\
\hline 31 & Kota Magelang & 22 kali \\
\hline 32 & Kota Pekalongan & 5 kali \\
\hline 33 & Kota Salatiga & 10 kali \\
\hline 34 & Kota Surakarta & 27 kali \\
\hline 35 & Kota Tegal & 5 kali \\
\hline
\end{tabular}

Bentuk dari kegiatan Roadshow Gubernur ada 6 (enam) yaitu : Ngopi Bareng/Rembukan; Gubernur Mengajar ; Silaturahmi ke Pondok Pesantren; Pengarahan SKPD Kabupaten/Kota; Peninjauan Infrastruktur dan Peninjauan UPT/Balai/UP3ADDari hasil identifikasi kegiatan roadshow yang dilakukan penulis, Peninjauan Infrastruktur adalah kegitan yang paling sering dilakukan. Rinciannya sebagai berikut:

Tabel 2: Bentuk Roadshow Tahun 2013-2017

\begin{tabular}{|c|l|r|}
\hline No & \multicolumn{1}{|c|}{ Bentuk Roadshow } & \multicolumn{1}{|c|}{ Jumlah (Kali) } \\
\hline 1 & Ngopi Bareng & 100 kali \\
\hline 2 & Gubernur Mengajar & 73 kali \\
\hline 3 & Kunjungan Ponpes & 30 kali \\
\hline 4 & Pengarahan SKPD & 14 kali \\
\hline 5 & Peninjauan Infrastruktur & 157 kali \\
\hline 6 & Peninjauan UP3AD/UPT/Balai & 77 kali \\
\hline
\end{tabular}

Kegiatan Roadshow yang meliputi Ngopi Bareng, Gubernur Mengajar, Kunjungan Pondok Pesantren, Pengarahan SKPD Kabupaten Kota, Peninjauan Infrastruktur dan Peninjauan UP3AD/ Balai/UPT menunjukkan perwujudan kewenangan:

1. Ngopi Bareng

Dalam kegiatan Ngopi Bareng, Gubernur Ganjar Pranowo menampung semua aspirasi/ permasalahan dari kelompok masyarakat yang dikunjungi. Misalnya Ngopi Bareng dengan Kelompok Nelayan, Nelayan mengeluhkan soal Perizinan Kapal, Permodalan, Penangkapan Ikan, Pengerukan Sungai, permohonan bantuan seperti : cold-storage, mesin pengasa-pan, lantai jemur dan terkait Keamanan Nelayan di Laut. Pengelompokan identifikasi masalah yang ada 
diatas, diminta kepada Dinas Lutkan untuk memfasilitasi perumusannya bersama nelayan yang diwakili dari pihak HNSI, pemilik kapal, ABK, Nahkoda, dan terdampak lainnya (bakul dan pengrajin jaring). Dari permasalahan tersebut, apakah menjadi kewenangan pemerintah pusat, provinsi atau kabupaten/kota. Yang selanjutnya akan ditindaklanjuti misalnya mengusulkan kepada pemerintah pusat, menyampaikan surat kepada Bupati atau kepada pihak yang terkait.

Jadi Kegiatan Ngopi Bareng, Gubernur sebagai Wakil Pemerintah Pusat menjalankan fungsi koordinasi penyelenggaraan pemerintahan antara pemerintah daerah provinsi dengan instansi vertikal, dan antar instansi vertikal di wilayah provinsi yang bersangkutan. Selain itu, gubernur juga menjalankan koordinasi penyelenggaraan pemerintahan antara pemerintah daerah provinsi dengan pemerintah daerah kabupaten/kota di wilayah provinsi yang bersangkutan

\section{Gubernur Mengajar}

Dalam kegiatan Gubernur Mengajar, Gubernur Ganjar Pranowo lebih menekankan pada nilainilai tentang budi pekerti, pendidikan kewarganegaraan, wawasan nusantara dan ajakan untuk mengedepankan musyawarah mufakat, gotong royong serta persatuan kesatuan bangsa agar lebih mencintai NKRI. Gubernur juga memotivasi para siswa agar lebih berbakat dan keatif sesuai dengan minat dan bakatnya. Gubernur Mengajar juga bertujuan untuk memberikan pendidikan politik kepada siswa, memberikan pemahaman tentang hak, kewajiban dan tanggungjawab setiap warga negara kepada bangsa dan negara. Jadi Kegiatan Gubernur Mengajar, gubernur tidak menjalankan peran dan fungsinya sebagai Wakil Pemerintah Pusat tetapi lebih kepada memberikan pendidikan politik dan kebangsaan kepada siswa.

\section{Silaturahmi ke Pondok Pesantren}

Dalam Silaturahmi ke Pondok Pesantren, yang bertujuan untuk saling meningkatkan silaturahmi dan menjaga kerukunan dan kekompakan. Peran Kyai penting dalam kehidupan masyarakat karena dikategorikan sebagai elit pada tataran masyarakat Indonesia. Secara ideal seorang kyai berperan sebagai figur moral dan pemimpin sosial, serta tokoh sentral dalam masyarakatnya, sebab di bahu merekalah terletak cita-cita dan eksistensi umat. Oleh karena itu ukuran seorang Kyai tidak dapat hanya dilihat dari segi apa yang dilakukannya dan dari karakteristik pribadinya saja, tetapi yang penting sejauh mana masyarakat memberikan pengakuan kepadanya.

Kegiatan Silaturahmi ke Pondok Pesantren, gubernur sebagai Wakil Pemerintah Pusat memiliki peran dan fungsi menjalankan pemerintahan umum yaitu memperkuat persatuan dan kesatuanbangsa; dan menjaga stabilitas politik, keamanan bangsa.

\section{Pengarahan SKPD Kab/Kota}

Kegiatan Pengarahan SKPD Kabupaten/kota dalam roadshow gubernur bertujuan untuk sinergitas perencanaan pembangunan dari aspirasi/usulan kegiatan kabupaten kota. Namun demikian, tidak semua aspirasi tersebut merupakan kegiatan prioritas yang dibutuhkan untuk menyelesaikan permasalahan strategis di daerah. Dengan demikian tentunya beragam aspirasi 
tersebut perlu diselaraskan dengan kebutuhan dalam dokumen perencanaan sebagai acuan dasar rencana program/kegiatan yang perlu dilaksanakan untuk mengatasi permasalahan-permasalahan daerah.

Mengenai fungsi pembinaan melalui fasilitasi dan konsultasi dari pemprov kepada pemkab/ pemkot telah terselenggara dengan baikmelalui fasilitasi dan konsultasi pembentukan unit pelayanan terpadu di kabupaten/kota. Sedangkan untuk bagian hukum, pembinaan fasilitasi dan konsultasi cukup intens terutama terkait dengan peraturan daerah, seperti pelatihan penyusunan Perda, perancangan Perda, pembahasan Perda, ataupun sosialisasi Perda.

Mengenai fungsi pengawasan penyelenggaraan pemerintahan daerah kabupaten/kota, hal ini merupakan tugas gubernur yang cukup penting untuk dimaksimalkan dalam rangka menciptakan kesatuan arah koordinasi gubernur dan walikota/ bupati. Untuk pengawasan melalui evaluasi Perda, dimana pembahasan dan diskusi Raperda dilakukan secara intensif dan melibatkan pakar di bidang hukum dan bidang teknis terkait. Raperda kabupaten/kota yang wajib dievaluasi gubernur adalah Raperda yang menyangkut pajak daerah, retribusi daerah, APBD, dan tata ruang.

Jadi Kegiatan Pengarahan SKPD Kabupaten/kota, gubernur sebagai Wakil Pemerintah Pusat menjalankan fungsi :

a) Gubernur mengkoordinasikan penyelenggaraan pemerintahan daerah provinsi, kabupaten/ kota;

b) Gubernur melakukan sinkronisasi dan integrasi perencanaan pembangunan daerah kabupaten/kota dengan perencanaan pembangunan daerah provinsi dan pusat;

c) Gubernur melakukan sinkronisasi program dan kegiatan pemerintah kabupaten/kota dengan provinsi dan pemerintahpusat;

d) Gubernur melakukan pengawasan terhadap bupati/walikota dalam menyelenggarakan pemerintahan;

e) Gubernur melakukan supervisi, monitoring, dan evaluasi program dan kegiatan yang dilaksanakan oleh kabupaten/kota;

f) Gubernur melakukan pembinaan terhadap urusan pemerintahan yang dilaksanakan oleh pemerintahkabupaten/kota.

5. Peninjauan Infrastruktur

Kegiatan Peninjauan Infrastruktur adalah kegiatan yang paling banyak dilakukan dalam roadshow Gubernur Ganjar Pranowo. Gubernur Ganjar Pranowo rutin melakukan peninjauan infrastruktur baik itu kewenangan pusat, provinsi maupun kabupaten/kota. Kemudian yang berkaitan dengan kewenangan Gubernur, semua aspirasi yang masuk terkait peninjauan infrastruktur untuk selanjutnya masuk dalam prioritas kegiatan OPD. Selanjutnya follow up sesuai dengan kebijakan Pemerintah baik Pusat, Provinsi dan Kota/Kabupaten. Contohnya peninjauan jalan dan jembatan, embung/ waduk, pelabuhan dan bandar udara. Pembangunan infrasrtuktur yang baik akan berdampak 
pada kesejahteraan masyarakat di daerah maupun mendukung pembangunan nasional secara lebih luas. Dari hasil roadshow, pembiayaan infrastruktur bisa masuk usulan Penanganan Sektoral (Pusat dan Provinsi) dan Usulan Penanganan Melalui Bantuan Keuangan (Provinsi).

Dalam Peninjauan Infrastruktur, gubernur sebagai Wakil Pemerintah Pusat menjalankan fungsi :

a) Gubernur mengkoordinasikan penyelenggaraan pemerintahan daerah provinsi, kabupaten/ kota;

b) Gubernur melakukan sinkronisasi dan integrasi perencanaan pembangunandaerah kabupaten/kota dengan perencanaan pembangunan daerah provinsi dan pusat;

c) Gubernur melakukan sinkronisasi program dan kegiatan pemerintah kabupaten/kota dengan provinsi dan pemerintahpusat.

6. Peninjauan UP3AD/Balai/UPTD

Dalam roadshow, Gubernur Ganjar Pranowo keliling UP3AD/Samsat di 35 kabupaten kota se Jawa Tengah. Hal ini bertujuan agar masyarakat tidak dirugikan dengan adanya oknum yang memungut biaya tambahan saat membayar pajak kendaraan bermotor dan memberantas praktek pungutan liar (pungli). Selain mengunjungi UP3AD, gubernur juga mengunjungi Balai/UPT milik Pemerintah Provinsi: Balai Besar Pembibitan Ternak Unggul dan Hijauan Pakan Ternak,Balai Inseminasi (Pengembangan pembibitan benih sapi unggul), Balai Pembenihan Budidaya Ikan Air Tawar dan Ikan Payau, dan Balai Rebsos Disabilitas. Gubernur melakukan peninjauan agar pelayanan semakin cepat mudah murah dan efisien dalam rangka penegakan reformasi birokrasi. Jadi kegiatan Peninjauan UP3AD/Balai/UPT tidak mencerminkan pelaksanaan Fungsi dan Peran Gubernur sebagai Wakil Pemerintah Pusat.

Berlangsungnya keenam kegiatan roadshow itu tidak lepas dari dukungan beberapa faktor. Tanpa ada kebijakan yang diterapkan oleh Pemerintah Provinsi Jawa Tengah, kegiatan-kegiatan itu tidak ada tercapai. Selain itu, dukungan moral dan politik Gubernur Ganjar Pranowo terhadap masyarakat juga signifikan perannya sehingga meningkatkan partisipasi warga dalam roadshow. Begitu juga bentuk kegiatan yang menarik, seperti forum publik yang dikemas menjadi diplomasi kopi.

Meski berjalan cukup sukses, namun ada beberapa hambatan yang muncul selama pelaksanaan kegiatan. Salah satunya adalah adanya keterbatasan anggaran. Tidak hanya itu, program ini juga sering kali dikritik sebagai sarana kepentingan politik sang Gubernur. Utamanya, hambatan terbesar adalah kurang sinkronnya kebijakan pusat, provinsi, kabupaten dan kota dalam kebutuhan untuk sosialisasi dan dekat dengan rakyat.

\section{Penutup}

Roadshow Gubernur Ganjar Pranowo Tahun 2013-2017 dilakukan tidak merata atau terjadi ketimpangan di 35 kabupaten kota. Dengan rincian Kabupaten yang sering dikunjungi adalah Kabupaten Cilacap sebanyak 36 kali dan Kabupaten yang jarang dikunjungi adalah Kabupaten 
Sukoharjo dan Kota Magelang sebanyak 2 kali. Bentuk dari kegiatan Roadshow Gubernur ada 6 (enam) yaitu: Ngopi Bareng/Rembukan; Gubernur Mengajar; Silaturahmi ke Pondok Pesantren; Pengarahan SKPD Kabupaten/Kota; Peninjauan Infrastruktur dan Peninjauan UPT/Balai/UP3AD.

Kegiatan Roadshow Gubernur di 35 kabupaten/kota mencerminkan sebagian besar perwujudan peran dan fungsi gubernur sebagai wakil pemerintah pusat di daerah dan menjalankan kewenangan atributif (fungsi kordinasi,pembinaan dan pengawasan). Dari 6 (enam) Kegiatan hanya 4 yang mencerminkan perwujudan peran dan fungsi gubernur sebagai wakil pemerintah pusat yaitu: Ngopi Bareng/Rembukan; Silaturahmi ke Pondok Pesantren; Pengarahan SKPD Kabupaten/Kota dan Peninjauan Infrastruktur.

\section{Ucapan Terima Kasih}

Penulis mengucapkan terima kasih pada semua pihak yang telah membantu dalam penelitian ini.

\section{Pendanaan}

Penulis tidak menerima bantuan pembiayaan untuk penelitian, kepenulisan (authorship), dan publikasi dari pihak manapun.

\section{Daftar Pustaka}

Andy, R., \& Bakry, L. (2009). Politik dan Pemerintahan Indonesia. Jakarta: Masyarakat IImu Pemerintahan Indonesia.

Depdiknas. (2005). Kamus Besar Bahasa Indonesia. Jakarta: Balai Pustaka.

Fried, R. (1963). The Italian Prefects: A Study in Administrative Politics. London: Yale university Press.

Jones, G. W. (1985). Local Government and Field Administration: Some Models. London: School of Economic.

Kaloh, J. (2010). Kepemimpinan Kepala Daerah; Pola Kegiatan, Kekuasaan, dan Perilaku Daerah Dalam Pelaksanaan Otonomi Daerah. Jakarta: Sinar Grafika.

Soekanto, S. (1975). Sosiologi Suatu Pengantar. Jakarta: UI Press.

\section{Tentang Penulis}

Erlin Nur Marfuah adalah Pegawai Negeri Sipil (PNS) di Biro Administrasi Pembangunan, Sekertariat Daerah Provinsi Jawa Tengah. Alumni Magister IImu Politik, Universitas Diponegoro ini menggeluti area riset seputar komunikasi politik. 